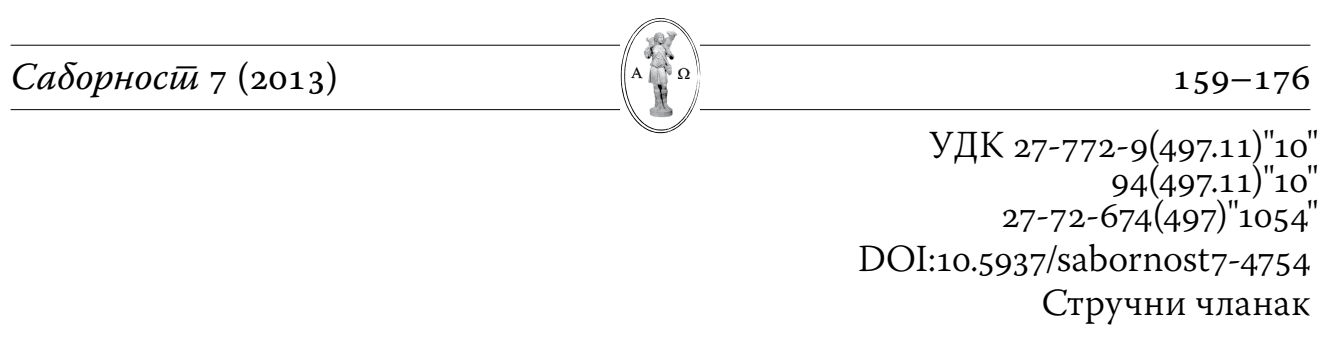

\title{
Радован Радић"
}

Хришћански културни центар, Београд

\section{Велики црквени раскол и његове последице на Балканском полуострву - XI вијек у Зети. Улога српских владара у оснивању Барске архиепископије}

\begin{abstract}
: Једанаести вијек на Балканском простору представља доба вишедеценијског пропадања Византијске империје, као и наглог успона нормандијске јужноиталијанске струје, која своје интересе види и са друге стране Јадранског мора. Наиме, велики црквени раскол драстично утиче на међудржавне односе, што се примјећује при укидању Василијевих архиепископија, али и при подизању нових римских црквених центара на традиционално источним територијама. Овдје је ријеч о чувеној Барској архиепископији и улози српских владара у њеном подизању. Међутим, поставља се питање: колика је та улога заправо била?
\end{abstract}

Key words: црквени раскол, Барска архиепископија, Зета, Михаило, Бодин.

Ц рква Христова у XI вијеку проживљава своје највеће искушење, које доводи до раздвајања њенога тијела на Источну (Православну) и Западну (Римокатоличку) Цркву. Разлози који су проузроковали велики црквени раскол били су углавном догматске природе, али и директно повезани с разликама у обичајима и менталитетима двије цивилизације.

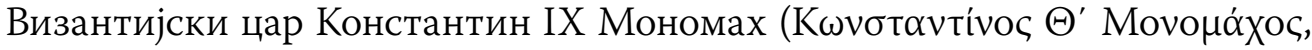
1042-1055), као и његови наследници, показао се као неспособан у рјешавању црквених несугласица које подједнако разарају Стари и Нови Рим - Цариград.

Догматске разлоге раскола можемо пронаћи у све чешћем коришћењу Filioque-a од стране Латина при исповиједању вјере као и у разлици у црквеним обичајима који су се у X и XI вијеку потенцирали посебно у византијској јужној Италији. У француској покрајини Бургундији (region Bourgogne) 910. године је основан монашки ред у Клинију (Cluny) ${ }^{1}$, чији

\footnotetext{
r_radovan@hotmail.com

1 Ред је играо запажену улогу у животу Римокатоличке Цркве. Угушен је у Француској
} 
су се припадници залагали за унутарцрквени духовни препород; њихово проширење на цијели Запад даје жестоке поборнике папизма и актере 2 који су директно учествовали у великом црквеном расколу. Политички, територијалне претензије на јужну Италију оставиле су дубок траг у везама између Истока и Запада. У освит ХІ вијека јужна Италија се појављује управо као непремостиви јаз у везама. Јачање Отона I (Otto I, †973) на Западу, оснивање германскога царства Свейа римска имйерија іерман-

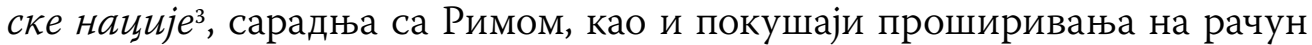
византијских територија додатно отежавају већ тешку ситуацију између Старога и Новога Рима. Свакако, логично је да се и у званичном Риму

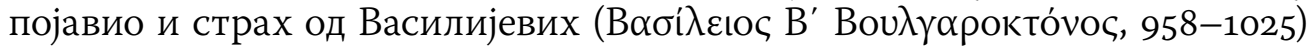
освајања Балкана и подручја јужне Италије. Његове границе су стизале на неких 300 км од Рима, изнад града Барија, док су се на Балканском полуострву протезале све до подножја Алпа. Обрачун са царем Самуилом (997-1014) и реорганизација Цркве у Бугарском царству доводи до тога да се унутар црквених кругова у Риму критички гледа на црквену политику византијских императора. Када је ријеч о реорганизацији Цркве, ту се прије свега мисли на укидање Бугарске патријаршије од стране Василија, као и оснивање Прве Јустинијане или Охридске архиепископије на истим територијама. Међутим, Рим се све више залагао за придобијање већ постојећег свештенства и народа против Цариграда, позивајући се на спорни докуменат о првенству Рима Donatio Constantini ( $\psi \varepsilon v \delta o-K \omega v-$

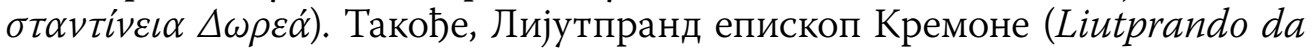
Cremona), службеник цара Отона, у својим дјелима се посебно истиче својом противвизантијском реториком ${ }^{4}$. Популарна пропаганда међу западним богословима XI вијека јесте то што је све до X вијека цариградски патријарх био под канонском јурисдикцијом Рима, што потврђује и чињеница да му је приликом устоличења слат палијум лат. Pallium, грч.

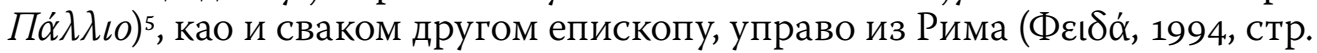
160-161). Ова чињеница, по њиховим тврдњама, потврђује управо првенство Старога Рима.

У Цариграду се 16. јула 1054. између двије патријаршије воде преговори, који ће имати неславан крај. Римска делегација, предвођена кардиналом Умбертом (Humbert), архиепископом Петром и ђаконом Фредериком, од априла се већ налазила у Цариграду. Сам римски папа Лав IX (Leo Nonus,

револуцији, 1790. године.

2 Папа Лав IX, Стефан и кардинал Умберто.

3 Sacrum Romanum imperium germanicae nationis.

4 Лијутпранд је остао познат по капиталним дијелима: Relatio de legatione constantinopolitana и Liber de rebus gestis Ottonis magni imperatoris.

5 У Старом Риму палијум је био римска ношња све до трећег вијека, када званично улази у кругове Цркве. Касније се код архијереја развија у један облик омофора. Данас је то оковратник код латинских свештеника. 
†1054) од фебруара 1053. године налазио се притворен у дворцу града Беневета (Benevento) од стране Нормана, који су га заробили након битке коју је лично папа предводио (Фєเ $\alpha \dot{\alpha}, 1994$, стр. 167). Патријарх цариград-

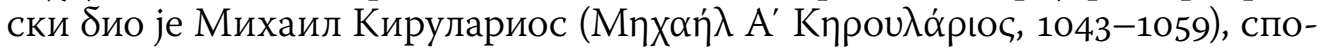
собна личност са великим црквеним, али и државним искуством ${ }^{6}$. Дуги ठоравак кардинала и његове пратње у Цариграду протекао је под заштитом императора и у знаку жестоких богословских дискусија. У суботу горенаведеног датума, на великој вечерњој молитви у величанственом храму Свете Софије у Цариграду, представници папе Лава IX (Острогорски, 1996, стр. 319) са својим вођама положили су на часну трпезу папску булу којом изопштавају патријарха Кируларија и његове истомишљенике (Migne, 1864a, стр. 741-746). Пошто су одбили да узму своју булу, један од ђакона из храма Свете Софије ју је избацио из цркве. Најистакнутији по-

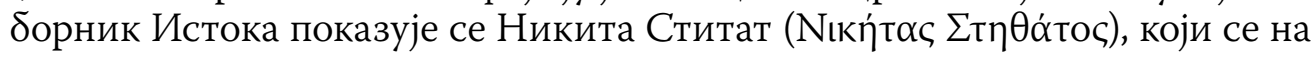
крају, под притиском, морао правдати за своје поступке.

Патријарх и његови сарадници су наговјештавали учешће личног Ки-

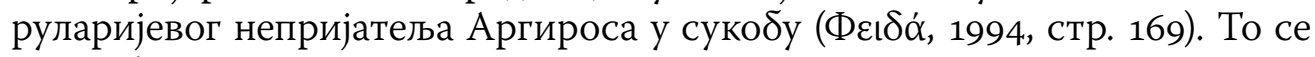
примјећује касније у преписци са патријархом антиохијским, јер су се кардиналови печати битно разликовали од печата папе Лава. Непријатељство према патријарху Кируларију се да̂ примијетити и из самога текста западних изасланика, који, поред догматских теза, обилује осудама на рачун патријарха (Migne, 1864a, стр. 743-745). Такође, нисмо сигурни када је до Цариграда стигла вијест о папиној смрти у заточеништву дворца у Беневету (15. април) (Migne, 1864a, стр. 743-745). Реакција патријарха цариградског је одмах услиједила. Уз пуну подршку императора, свештен-

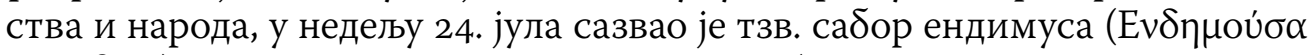

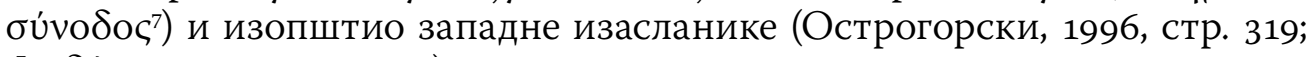
Фєاठ́́, 1994, стр. 171-172).

У великим културним центрима Истока и Запада раскол се одмах прочуо. Међутим, није тако било у удаљеним областима, које су биле насељене другим народима, па ни у српским областима и у Диоклији. У центрима пентархије раскол се прочуо одмах након тог догађаје, што се може видети и из опширних преписки између патријаршија. Патријаршије у Александрији, Антиохији, Јерусалиму, као и архиепископија

6 Прије свога патријарховања, Михаил је имао запажену политичку улогу у државној управи Византије. За вријеме владавине цара Михаила IV Пафлагона (1034-1041), са својим братом бива ухапшен и протјеран због уроте аристократије против цара. Након Пафлагоновог пада враћен је у Цариград, док за вријеме владавине цара Константина IX Мономаха (1042-1055) јача његова моћ у Палати, након чега и постаје патријарх (ФєІઠ́́, 1994, стр. 166-167).

7 Сабор у Цариграду. Израз $\varepsilon v+\delta \dot{\eta} \mu о \varsigma$ има значење мјесног сабора, тј. у општини - у овом случају у Цариграду. Засједали су углавном епископи града Цариграда, они који су ту били распоређени. 
Охридска, одлучно држе страну Истока. Примјећује се да у преписци између Кируларија и Петра III, патријарха антиохијског, влада једно опште мишљење како су западни изасланици били под изразитим утицајем Аргироса (Migne, 1864a, стр. 784), те да се још увијек на Истоку јулским догађајима одиграним у царском граду не даје значај коначног црквеног

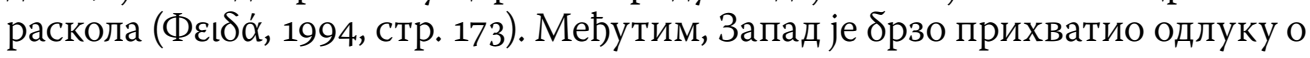
расколу као коначну. Након раскола, Римском црквом су управљали сами актери цариградских догађаја: кардинал Умберт и ђакон Фредерик, који 1057. постаје папа и добија име Стефан IX (Stephanus Nonus, †1058). Сабор у Бару, одржан 1098. године, осуђује као јерес свако неупотребљавање учења filioque у симб олу вјере. Врло брзо Римокатоличка Црква показује претензије на византијске територије у јужној Италији, али и у Илирику. Такође, папа Никола II (Nicolaus Secundus, †1061) признаје Роберта Гвискарда (Robert Guiscard, †1085) за јединог владара тадашње јужне Италије

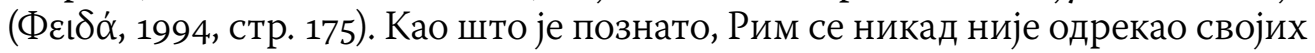
изіубльених йрава над цијелим источним Илириком ( $\sum \tau \varepsilon \phi \alpha v i ́ \delta o v, ~ 1948$, стр. 270). Врши се веома јак утицај на те крајеве, а посебно на приморске области, у којима су живјели Ромеји. Карактеристични су и потези Рима ради проширења њихове власти, како црквене, тако и политичке.

Словенски народи, Срби и Хрвати, највероватније су дуго били необавијештени о расколу и о разликама између Истока и Запада. Томе је у великој мери потпомогла и језичка баријера. Другим ријечима речено, римокатолици у приморским областима су као богослужбени језик користили латински, а православци на сјеверу су имали свој богослужбени језик. Међутим, врх црквене управе је био византијски, који је употребљавао грчки језик.

На подручју Хрватске, након слабљења Византије, створиле су се двије различите струје: једна која је подржавала глагољицу и друга која је подржавала латински као богослужбени језик. Суштински, проблем је био у разлици између источних и западних обичаја. Прва струја је нашла себи упориште у простом народу, док је у другој струји преовладавало свештенство. Након 1054. године и сабора у Латерану (1059) и Сплиту (1060) разлике у Хрватској су довеле до забране и протјеривања присталица глагољице ${ }^{8}$. Наравно, у том периоду словенски народи се још увијек нису црквено изградили, тако да се добро познати сукоб водио између великих хришћанских центара, Старога и Новога Рима.

Што се тиче првих српских држава, упознати смо са чињеницом да се те области дијеле - до 1089. године на двије западне архиепископије: Сплитску и Дубровачку, и од 1089. године: Сплитску и Барску, које су се налазиле под јурисдикцијом римског папе, као и архиепископију

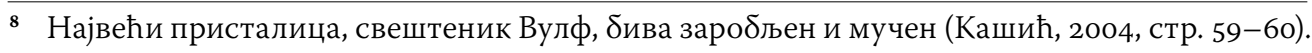


Охридску9 и митрополију Драч, које потпадају под духовну јурисдикцију патријаршије Цариграда. Расколом је подијељена Диоклија, и као што слиједи, српски народ, надвоје. Један дио њих се нашао под јурисдикцијом Цариграда, док је други био под римском. Дакле, становништво у приморским мјестима, близу римокатоличких центара у Бококоторском заливу, потпадало је под надлежност Римокатоличке Цркве, док је дио становништва који је насељавао сјеверније крајеве - ка Рашкој и потез испод Скадарског језера ка Бару - потпадао под географску надлежност Цариградске патријаршије. Међутим, у другој половини XI вијека долази до значајних промјена у Диоклији. Осјетни пад Византије након смрти Василија II Македонца (1025) и губљење територија на Балканском полуострву, као и велики црквени раскол, утицали су на помјерање црквених граница на поменутим територијама, тако да епископска сједишта основана у Диоклији током Василијеве реорганизације не налазимо у списку епископија митрополије Драча. Иста је у наведеном периоду сведена на митрополију Драч и четири епископије које су је окруживале (Darrouzes, 1981, стр. 364). Охридска архиепископија је углавном задржала своје епископије у Србији. Поменута подјела је била на снази све до времена Стефана Немање.

У времену после Василија Византијско царство је пролазило кроз озбиљну вишедеценијску кризу. Након битке код Маџикерта, 19. августа 1071, и пораза византијске војске, када је и заробљен цар Роман IV Дио-

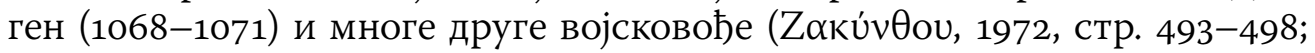
Ostrogorsky, 1989, стр. 234-238), нормански војсковођа Роберт Гвискард је освојио јужну Италију и Бар. Империја је била приморана да се организује, да би се одбранила, свом дужином својих граница. Византија је ишчекивала једног харизматичног и динамичног цара који би разријешио њене проблеме и пронашао излаз из озбиљне вишедеценијске кризе.

С друге стране, на територији Балканског полуострва појављују се многе народне вође, које покушавају искористити тренутну немоћ Византије ради отцепљења територија на којима је њихов народ био већински. Код Хрвата је ријеч о Звонимиру, док су код Срба на територији Травуније и Зете владали Гојимир, Михаил и Бодин (Љетопис попа Дукљанина, 1988, стр. 137-141). Последњи поменути владар, по свједочанству попа Дукљанина, првобитно напушта Зету и одлази на територије гдје је столовао Самуил ради обнављања његове државности и борбе против Византије. Све поменуте владаре друге половине XI вијека карактерише противвизантијско расположење, што се вјероватно одражава и на укидање византијске црквене организације на њиховим територијама.

9 Занимљив је податак да Охридска архиепископија у званичним каталозима Цариградске патријаршије носи назив Јустинијана Права или цијеле Бугарске (Darrouzes, 1981, стр. 371). 
164 | Радић, Р., Велики црквени раскол и њеїове йослеgице на Балканском йолуосиирву... -

Ово се односи на архиепископију Дубровачку, као и на епархије у Диоклији: Скадар, Диоклија, Дриваст и Бар. Званични Рим је свакако у нередима који су владали Балканом у другој половини XI вијека угледао своју прилику.

Римокатоличка Црква је брзо искористила ситуацију у којој се Византијско царство налазило и журно је радила на црквеном и политичком проширењу ка Илирику. Године 1075. у Хрватској се крунише вођа Димитрије Звонимир. Пажња Рима врло брзо се усмјерава на нову Михаилову државу. Двије године након крунисања хрватског вође (1077) владар Диоклије и вјероватно Травуније ${ }^{10}$ Михаил у Сплиту преговара са Петром, представником папе Григорија VII, о додјели краљевског звања (regalia ornamenta) и палијума Петру, тј. о уздизању Бара у ранг архиепископије (Farlato, Coleto, 1817, стр. 21; Историја Црне Горе, 1967, стр. 395). Његова држава се вјероватно због тога и називала Диоклија и Далмација (Стефан Првовенчани, 1988, стр. 73). Доментијан пак у своме дјелу српске земље назива Диоклийија, Далмайија, Травунија (Доментијан, 186о, стр. 3). Занимљив податак је да се Михаил и у латинској литератури ословљава као краљ Словена, али и краљ Срба: Michaele rege Serblorum (Farlato, Coleto, 1817, стр. 21).

\section{1. Теорија о улози Михаила и Бодина у оснивању Барске архиепископије}

Мишљење српских историчара - углавном старијих - о Михаилу јесте да је осим свога устоличења од римског понтифекса затражио и оснивање нове архиепископије, са центром у граду Бару. У датом моменту то је било немогуће, због супротстављања архиепископија Спалата и Дубровника, које су страховале да ће нова архиепископија изузети доста области из њихове духовне надлежности. То се поготово односило на архиепископију Дубровачку, јер је између ње и Бара владала видљива нетрпељивост: „никако дубровачки, него само барски архиепископски назив" ${ }^{\text {"11 }}$. Новооснована архиепископија би под својом влашћу имала све територије које су се налазиле под Михаиловом управом. На почетку своје владавине, према истом мишљењу, Михаил је признавао архиепископа града Дубровника. Међутим, касније, пошто је Дубровник признао власт Гвискарда, 1081. године, Михаил се окренуо оснивању архиепископије Бар. Такође, да би се остварило устоличење Михаилово, он би морао признати папску власт у својој земљи и потврдити да ће бити вјерно чадо папског

10 Нигдје се изричито не говори да су били владари само Диоклије или да су из ње. Са страница родослова се да̂ закључити да су истовремено једно вријеме као породица владали Травунијом, која је била централна област (Љетопис попа Дукљанина, 1988, стр. 137-138).

11 „[N]ullo modo Ragusinum, tantummodo Antibarensem Archiepiscopus appellat“ (Farlato, Coleto, 1817, стр. 22). 
трона. Из историјских извора који су нам доступни, не знамо да ли је или како је извршено ово крунисање, односно да ли је папа само послао круну или се десио регуларни чин, као што је то случај при крунисању западних краљева након Карла Великог (Carolus Magnus, 768-814), гдје је папа светим миром помазивао и крунисао будућег краља. Ријечи из папске посланице 1078. године „част своју краљевства од нас признату“12, према поменутом мишљењу, управо се односе на крунисање Михаилово од стране римског понтифекса.

Оснивање прве архиепископије која је покривала све српске територије одвија се три деценије после великог црквеног раскола, за вријеме владавине Бодина. Ријеч је о римокатоличкој архиепископији Бар, која је утемељена 8. јануара 1089, за вријеме антипапе Климента III (Кашић, 2004, стр. 66) и папе Урбана II (Urbanus Secundus, 1088-1099). Сједиште архиепископије се налазило у византијском граду Бару. Године 1085, после смрти Роберта Гвискарда, између византијске војске и Нормана воде се одлучујуће битке. Бодин се није упуштао у сукобе, иако су и Византинци и Нормани очекивали да у борбама стане на њихову страну. Касније је, борећи се са својом војском, проширио своју власт на Рашку и Босну. Његова држава је била у видном успону.

Према наведеном ставу историчара̂, Бодин, као и његов отац Михаил, имајући жељу да избјегне утицај архиепископије Дубровачке, одлучује да оснује архиепископију унутар своје државе. Архиепископија Охридска и митрополија Драч, пошто нису имале велики утицај на његове области, нису представљале велику опасност. Бодин је замолио папу да епископију Бар уздигне на ранг архиепископије и Петру уручи палио архиепископски. Сматрао је да ће му овај потез помоћи у стабилизацији његове државе. У међувремену, искористио је сукобе који су постојали у Римокатоличкој цркви између регуларних папа, Виктора III (Victor Tertius, 1086-1087) и Урбана II, и антипапе Климента III (Clement III, 10801100), као и нерасположење које је у Риму владало према архиепископији Дубровачкој.

Наравно, ради се о много већим размирицама и сукобима који су се распламсали између Старог и Новог Рима након великог црквеног раскола. Стари Рим је искористио Бодинове ратове и нетрпељивост према Византији, која је доживјела осјетни пад у другој половини ХІ вијека. Осим тога, тежило се повратку својих изіубљених йрава у Илирику, која су укинута још давне 732, за вријеме владавине Исавријанаца. Василијеве византијске архиепископије у јужној Италији и на Балканском полуострву су редом укидане. С друге стране, Византија је затварала римске манастире по Цариграду и околини. Наравно, за све ове догађаје на територији Бодинове државе била је потребна и његова сагласност.

12 „[T]uique regni honor a nobis cognosci“ (Farlato, Coleto, 1817, стр. 22). 
Сукоби између папе и антипапе су почели 1080. године. Германски краљ, Хајнрих IV (Heinrich IV, 1050-1106), због личних сукоба које је имао са папом Григоријем VII, продире у Италију и читаве три године опсједа Рим. Папа Григорије, уз помоћ Роберта Гвискарда и Нормана, успијева да избјегне из опкољеног Рима у Палермо у јужној Италији, где је и преминуо маја 1085. године (Линч, 1999, стр. 189-190). Краљ Хајнрих на упражњено папско мјесто поставља Климента III, кога је само он признавао и подржавао, док је остали римокатолички свијет био на страни одбјеглог папе. Пошто је на почетку сукоба Климент III био изразито јачи од својих противника, ठарски епископ Петар, уз Бодинову подршку, одлази код њега да затражи уздизање своје епископије у ранг архиепископије, као и звање архиепископа за себе. Постојање архиепископије града Дуठровника није сметало антипапи Клименту, а разлог више је био тај што је и сама архиепископија признавала прогнаног папу Урбана II (†1099). Дана 8. јануара 1089. Александар Сервус је прочитао булу којом се Петар проглашава архиепископом ठарским: „Александар Сервус, слуга Божији Петра часнога архиепископа диоклијске и барске Цркве, у Господу непрестано поздрављам “"13. Такође, папа Климент III назива Бодина краљем Словена: „син наш Бодин, краљ Словена најславнији“"14.

У складу с папском одредбом, под јурисдикцију нове архиепископије потпадају следећи градови: Дукља, Бар, Котор, Улцињ, Свач, Скадар, Дриваст, Пилот, као и цијеле области Србија, Босна и Травунија, са свим манастирима, како латинским, тако и грчким и словенским ${ }^{15}$. Области које су ठиле укључене у архиепископију Бар географски се шире јужно од Јадранског мора и сјеверно до ријеке Саве, западно од града Дубровника и ријеке Врбас до града Скадра и Рашке на истоку. Сви градови поменути у папској одредби налазили су се уз Јадранско море, осим три велике области: Србије, Травуније и Босне, које су биле додате на крају списка. Овај поредак области нас наводи на закључак да у последње три наведене области, Србија, Босна и Травунија, нису постојали јаки римокатолички центри. Највјероватније их је Рим имао у плану. Проширење Бодинове

13 „Alexander Servus servorum Dei Petro Venerabili Archiepiscopo Diocliensis atque Antibarensis Ecclesiae salutem perpetuam in Domino" (Farlato, Coleto, 1817, стр. 17)

14 „[F]ilii nostri Bodini, regis Sclavorum gloriosissimi...“ (Историја Црне Горе, 1967, стр. 397)

15 „Diocliensem Ecclessiam cum omnibus suis pertinentiis, Antibarensem Ecclessiam cum omnibus suis pertinentiis, Ejaterensem Ecclessiam cum omnibus suis pertinentiis, Palachiensem Ecclessiam cum omnibus suis pertinentiis, Svatinensem Ecclessiam cum omnibus suis pertinentiis, Scodriensem Ecclessiam cum omnibus suis pertinentiis, Dinnastinensem Ecclessiam cum omnibus suis pertinentiis, Polatinensem Ecclessiam cum omnibus suis pertinentiis, Serbiensem Ecclessiam cum omnibus suis pertinentiis, Boliensem Ecclessiam cum omnibus suis pertinentiis, Tibuniensem Ecclessiam cum omnibus suis pertinentiis, monasteria quoque tam Latinorum, quam Graecorum sive Slavorum cures, ut scias baec omnia unam Ecclesiam esse, teque omnibus praedictis locis Episcopali regimine praeesse“ (Farlato, Coleto, 1817, стр. 18; Историја Црне Горе, 1967, стр. 395-396) 


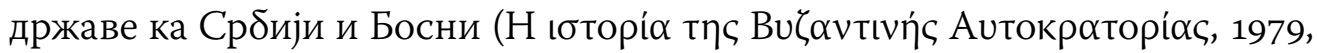
стр. 390) за време сукоба Византије са Гвискардом, сигурно би у великој мери допринијело остварењу ових планова.

Као што се може примијетити, наведене области су већ биле дјелимично потчињене јурисдикцији архиепископије града Дубровника. То је управо био и један од основних разлога за нетрпељивости које су услиједиле међу њима. Такође, области између ријека Саве, Дунава и Јадранског мора, односно области које је папа својом одредбом предао архиепископији Бар, од 1018. године су биле под духовном јурисдикцијом архиепископије Охридске и митрополије Драч, тј. Цариградске патријаршије. После великог црквеног раскола папа својевољно проширује своју власт и на неки начин покушава повратити права која је сматрао својим, а која су се тицала источног Илирика, истовремено нарушавајући расподјелу надлежности установљену давне 732. године. Ситуација у Илирику се одвијала на штету патријаршије Цариградске.

Војни поход против Бодина, који је водио кесар Јован Дука ${ }^{16}$, био је разлог застоја у проширењу јурисдикције архиепископа града Бара. Такође, страховити порази Нормана у Ипиру у околини Драча (Фєıઠ́́, 1997, стр. 116-117) од стране одлучног императора Византије Алексија I Комнина (1081-1118) ${ }^{17}$ негативно утичу на развој нове римске архиепископије у Бару. Бодин након свог пораза није више био тако јак у тим областима. Византијско царство га је приморало да врати већи дио територија које је раније освојио, као и да призна власт императора. Ни у самој Рашкој ситуација се није одвијала повољно за Бодина - налазио се у сукобу са Вуканом, који је тада имао највећу моћ на сјеверу. У то вријеме, Рашка је потпадала под црквену јурисдикцију Охридске архиепископије и зато архиепископ Бара ту није налазио толико жељену подршку. Архиепископија Бар на крају остаје ограничена на своја приморска мјеста, углавном у градовима гдје су боравиле латинске породице.

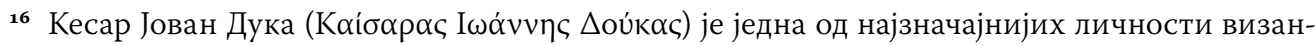
тијске престонице у другој половини XI вијека. Син је Андроника Дуке и брат императора Константина I. Нажалост, податке о његовом животу имамо тек након 1057. године. После 1071. године и пропасти цара Диогена, Јован у једном раздобљу постаје кључна фигура у цариградској Палати. Након пропасти своје политичке каријере, Јован Дука постаје монах и повлачи се на своје имање у Тракији. Иако се повукао, пружа сву подршку и утицај при збацивању с власти Никифора Вотанијатиса и доласку на власт Алексија I Комнина.

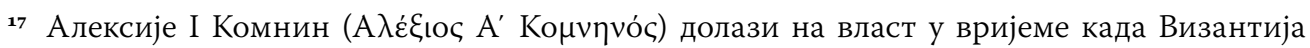
проживљава до тада најтеже тренутке своје вишевјековне историје. Империја се налази ठез новца, војске, флоте и територија. Алексије, искусан војсковођа али и дипломата, успијева потиснути Гвискарда из Ипира и од Селџука повратити византијске територије у Малој Азији. 


\section{2. Ситуација на Балканском полуострву током XI вијека. Оснивање Барске архиепископије}

Изложена теорија о оснивању Барске архиепископије од стране Рима у сарадњи са српским владарима јесте латинска - западног поријекла. У југословенску и касније српску историјску литературу уврштена је као резултат недовољног броја историјских извора и истраживања везаних за црквено уређење Диоклије XI вијека, и тако бива прихваћена од великог ठроја историчара као могући развој догађаја. Међутим, оснивање западне архиепископије након великог црквеног раскола на територијама традиционално потчињеним Цариграду заслужује додатно историјско истраживање.

Оснивање архиепископије у Бару је директна последица великог црквеног раскола. Већ смо поменули негативну атмосферу која је владала у односима Стари - Нови Рим након великог црквеног раскола. Наиме, ријеч је о нетолеранцији према источним обичајима, који су углавном загосподарили на територијама под управом цара Василија II. Сам Император, за вријеме своје владавине, на истим посједима врши одређену црквену реорганизацију. Тако, поред Охридске архиепископије, прије смрти у Дубровнику 1022. године оснива архиепископију. Такође, годину дана касније, 1023. године, у јужној Италији, у Апулији, оснива архиепископију Сипонда (Фєєઠ́́, 1994, стр. 165). Званични Рим у томе тренутку даје пуну подршку оснивању нових црквених центара. Ситуација на мапи југоисточне Европе XI вијека након смрти цара Василија II, 1025. године, и великог црквеног раскола, 1054. године, доживљава нови обрт. Империја губи огроман дио својих посједа на Балканском полуострву, али и у Малој Азији. Читавих педесет година Царство је пропадало и слабило, што је водило катастрофалном поразу и, први пут у вишевјековној историји, заробљавању императора у бици код Манџикерта ${ }^{18}$ 1071. године. Средином XI вијека, на Балканском полуострву, границе империје су изнад Драча.

Незавидну ситуацију Византије искориштавају Роберт Гвискард ${ }^{19}$ и Нормани, који заузимају град Бари и велики дио јужне Италије (Фєเઠ́́, 1994, стр. 175). Након поменутих освајања, продиру и на територије Бал-

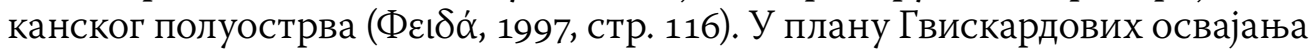
сигурно нису ठиле сјеверне територије, гдје се налазила Бодинова држава. Његови Нормани испловљавају на дијелу Јадранског мора у близини Драча и усмјеравају се ка истоку, тј. на византијско подручје (Migne, 1864в, стр. 405; Острогорски, 1996, стр. 336-337; Фعı $\delta \dot{\alpha}, 1997$, стр. 116). Првенствено им

18 Изнад Едесе, садашњи Malazgirt.

19 Занимљив је податак о почетку Робертових освајања. Кренуо је из Норманије са свега пет коњаника и тридесет пјешака. За врло кратко време на јадранским обалама постаје кључни војни фактор, који је држао главне поморске путеве (Migne, 1864в, стр. 136). 
је план био освајање Драча (Migne, 1864в, стр. 173), а касније је прерастао и у освајање другога по величини центра у империји - Солуна (Migne, 1864в, стр. 365) и, највероватније ${ }^{20}$, освајање што краћег пута преко Ипира, Македоније и Тесалије до Цариграда.

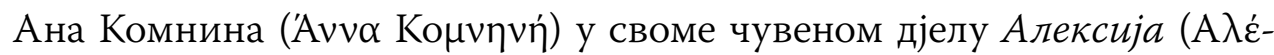
$\xi(\alpha)$ описује пораз свог оца, цара Алексија I, и слом његових одреда 1081. године у Ипиру код града Драча: „...сам Роберт пак као крилати витез са осталим снагама против ромејских одреда јуриша и њих потискује и на многе комаде разбија..." (Comnenae, 2001, стр. 160, 45-50; Migne, 1864В, стр. 360). Чак и ако су доживјели пораз, занимљив је начин величања борбе цара Алексија од његове ћерке: „...цар Алексије је пак као кула необорима остао..." (Comnenae, 2001, 160, стр. 50; Migne, 1864в, стр. 360). Роберт истовремено заузима и утврђени град Драч (Comnenae, 2001, стр. 159, 10).

Међутим, нејасно је учешће Бодина и његових „Далматинаца“" ${ }^{{ }_{21}}$ у овом историјском окршају, јер је он био један од запаженијих чланова византијске преговарачке војне елите уочи саме битке (Comnenae, 2001, 156, стр. 15; Migne, 1864в, стр. 352). Наредне године Роберт Гвискард је принуђен да се врати у Италију. Наиме, Аламанија, уз помоћ Рима, напада Лангобардију (Migne, 1864в, стр. 396). Роберт, према византијским историјским изворима, жели да освоји Рим (Migne, 1864в, стр. 396). На другој страни Јадрана, Млечани ${ }^{22}$, у том тренутку савезници цара Алексија, заузимају Драч (Mi-

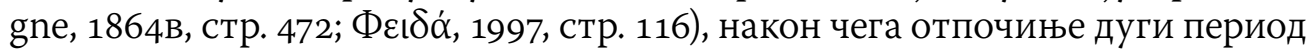
владавине Византије у тим крајевима.

У црквеном погледу, митрополија Драч током Гвискардових освајања трпи страховита разарања. На основу каталога Цариградске патријаршије

2 У питању је мишљење великог броја историчара, мада чињеница није историјски у изворима доказана, као нпр. Драч и Солун. Његова војска, након пада Драча, осваја територије данашње Македоније и креће путем централне Грчке. Овај курс је свакако различит од онога према Цариграду.

21 Ана овде и у другим дијеловима користи израз „Далматинци“ да би окарактерисала

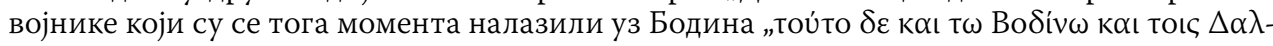

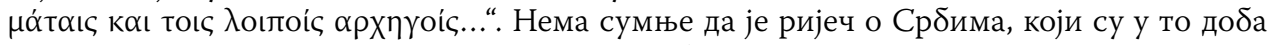
једини становници Далмације, којом управља Бодин. Његова држава се вјероватно тако и називала, као што смо већ у раду спомињали. Наиме, Ана, која је члан царске породице и упућена у византијску спољну дипломатију, Михаила и Бодина посматра као егзархе области Далмације, тј. Далматинаца, што се може примијетити у њеним наводима: „А

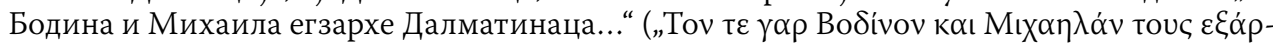

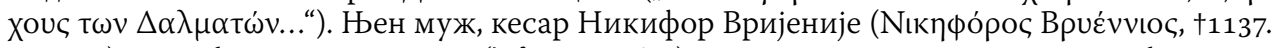

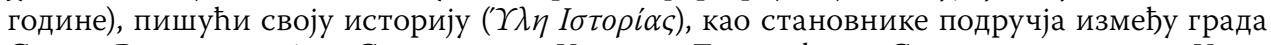
Скупи, Видина и ријека Саве помиње Хрвате и Диоклићане „С оне стране су опет Хрва-

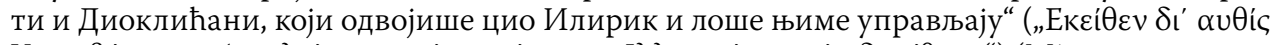
Х 173-175; Migne, 1864ס, стр. 144).

22 Поп Дукљанин наводи да је Бодин преузео Драч и околину након Гвискардове смрти (Љетопис попа Дукљанина, 1988, стр. 139). 
закључујемо да та митрополија, са петнаест епископија почетком XI вијека (Darrouzes, 1981, стр. 330), након Гвискардових освајања успијева опстати само на четири своје епархије (Darrouzes, 1981, стр. 364). Римокатоличка Црква је Гвискардова заузимања византијских подручја у јужној Италији и Балкану посматрала као јединствену прилику да сузбије византијски утицај, који се, као што смо навели, простирао и до изнад града Барија, на неких 300 км од самога Рима. Наиме, у Риму је на власти струја која је директно учествовала у великом црквеном расколу. Савез између Римске Цркве и Роберта Гвискарда је склопљен вјероватно и прије почетка његових освајања Италије: „...папа Римски... тежио је савезу са Робертом, већ чувеном по догађајима и за велика дијела стасалим..."23. Обје стране желе да се разрачунају са Цариградом. Освајање територија, укидање нових архиепископија и затирање источних обичаја свакако је њихов при-

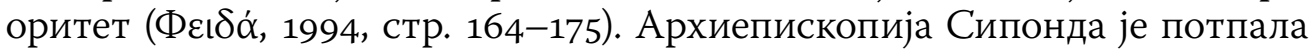

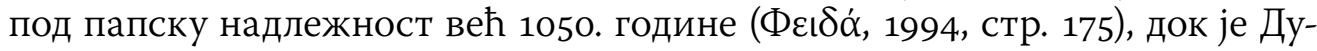
бровник изгубио јурисдикцију уздизањем Бара на ранг архиепископије.

Оснивање нове архиепископије, која би обухватала просторе на којима живе Срби, подудара се са тежњама Рима ка повратку својих изгубљених права на подручју источног Илирика. Срби су насељавали велики дио ових подручја и њихове границе су стизале до самих византијских територија. Горе наведено слабљење византијске моћи и успон скандинавског племена Нормана у јужној Италији, ствара идеалне услове за остварење папских тежњи у Илирику. Њихов утицај на Диоклију се огледа у браку склопљеном између Бодина и Јаквинте (Љетопис попа Дукљанина, 1988, стр. 140), кћери Архириза, вође норманске струје из италијанског града Барија (Историја Црне Горе, 1967, стр. 395). Слабљење византијске државне моћи подудара се и с опадањем утицаја Цариградске патријаршије у Диоклији. По последњој црквеној реорганизацији, из доба Василија, Диоклија је потпадала под јурисдикцију митрополије Драч. Једна од њених епархија је, као што смо претходно навели, Антибари - Бари (лат.

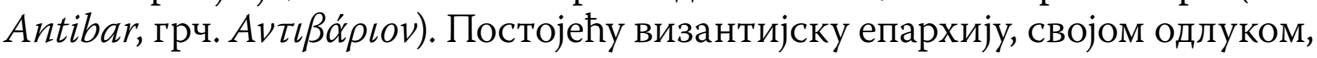
званични Рим уздиже на ранг архиепископије. Овај догађај није изузетак, узимајући у обзир временски оквир у коме се одвија, непосредно после раскола, и догађаје у Јужној Италији, који имају сличан сценарио. Међутим, из нама доступних извора не можемо са сигурношћу утврдити да ли је Петар био епископ града Бара, који је добио папски палио, или је у тренутку уздизања на ранг постављен на то мјесто.

У латинској литератури је прихваћена и потврћена чињеница да Александар Сервус произноси папску булу, којом Бар постаје архиепископија, 106о. године у Риму (Farlato, Coleto, 1817, стр. 17), за вријеме папе

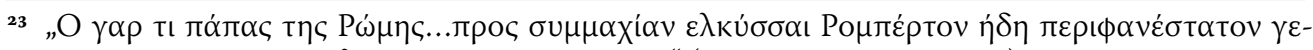

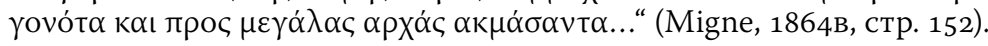


Александра $\mathrm{II}^{24}$. Ово датирање је свакако прихватљивије од датирања у 1089. годину, због радикалног понашања које је након самог раскола владало у односима између Старог и Новог Рима. Такође, Византија је 1089. године, са царем Алексијом I Комнином, већ повратила своју снагу у овим крајевима, док је Бодин поштовао надмоћ свога сусједа. Период дјеловања архиепископије Бар након 106о. није познат. Посебно је проблематичан период када је Петар отпочео дјеловање у Бару као архиепископ. Из историјских извора сазнајемо да осамнаест година након примања архиепископског достојанства, 1078. године, папа Григорије VII шаље Михаилу посланицу у којој Петра још увијек назива само епископом града Бара (Farlato, Coleto, 1817, стр. 22). Истовремено, папа предлаже избор другога нунција умјесто Петра, и то из њихових редова - припадника архиепископије Спалата (Farlato, Coleto, 1817, стр. 22)! Такође, податак вриједан пажње јесте период између Петрове смрти и избора наредног, тј. другог архиепископа Бара. Наиме, постоји одређени временски вакуум, пошто је нови архиепископ барски, Григорије, изабран тек у следећем вијеку, 1172. године (Farlato, Coleto, 1817, стр. 17).

На основу наведеног изводимо закључак да оснивање Барске архиепископије временски постављамо између великог црквеног раскола 1054. године и доласка на власт Алексија I Комнина, 1081. године. То је период слабљења Византије и надирања Нормана из јужне Италије. Време стагнације Барске архиепископије је доба Алексијеве владавине Византијом, све до друге половине XII вијека, када империја, након Мануилове владавине, поново слаби, што доводи и до пада Цариграда под крсташе 1204. године.

Јурисдикција Барске архиепископије је била захтјевна. Подручја која су јој додијељена протезала су се од Јадранског мора на југу до ријека Саве и Дунава на сјеверу. Западно јој је била потчињена Травунија, тј. области до Дубровника, док је на истоку стизала до нових граница митрополије Драч, до ријеке Дрим и града Љеша. На сјеверу својих нових подручја јурисдикција Барске архиепископије се поклапа са Охридском архиепископијом. Ријеч је о територијама изнад Скадра и Диоклије, до ријека Саве и Дунава.

Догађај који изазива додатну пажњу јесте учешће Михаила и Бодина у оснивању Барске архиепископије и додјела краљевске круне. Цијела теорија, описана на претходним страницама овога рада, о истовременом уздизању на ранг архиепископије и примању круне, нажалост, нема потребно упориште у историјским изворима. Дакле, у папској посланици из 1078. године исти упознаје Михаила са чињеницом да Петар још увијек није примио палио за архиепископа града Бара. Међутим, у уводном слову

24 У званичним папским каталозима „Рара Alexander Secundus Episcopus Romanus“ управља Римском Црквом од 1061. до 1073. године. 
ове посланице Михаила римски понтифекс поздравља као краља Словена (Farlato, Coleto, 1817, стр. 22). Зато је сасвим погрешно мишљење да се ријечи из посланице папе Григорија „част своју краљевства од нас признату“" односе на Михаила ${ }^{25}$. Ријеч је о правном положају (justitia possit) за који Дубровник као оштећена страна у размирицама са Баром тек треба

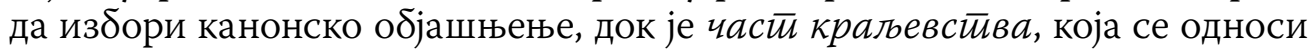
на политичку власт, она која је према „Псевдо-Константиновим даровима“ (Donatio Constantini) призната папи од самога цара Константина Великога. Наглашавање Константинове заоставштине је карактеристично за средњи вијек, а поготово за период након великог црквеног раскола, те током папског уплитања у политичку власт у Европи.

На страницама Барског родослова писац, чак иако првосвештеник припадник Римокатоличке Цркве, не наводи догађаје о оснивању своје надлежне архиепископије и истовременог крунисања краља од стране римског пондифика, исти наводи Бодиново крунисање током ратова са Византијом, након чега је проглашен царем Бугара (Љетопис попа Дукљанина, 1988, стр. 138). Вјероватно због поменутог крунисања, током подизања епископије Бара у ранг архиепископије, папа Климент III је назвао Бодина краљем Словена, а не Срба: „син наш Бодин, краљ Словена најславнији“26. Бодин је, према истом свједочанству, након тога чина разбјеснио византијског императора, после чега бива заробљен и послат у заробљеништво у далеку Антиохију (љетопис попа Дукљанина, 1988, стр. 138). Према родослову, занимљив податак је да Бодин на своју главу ставља круну прије смрти свога оца Михаила (Љетопис попа Дукљанина, 1988, стр. 138).

Чињеница која нас може упутити на то да су Михаил и Бодин били припадници Римске Цркве јесте догађај њиховог погреба „како доликује краљу“, у манастиру Светих мученика Сергија и Вакха (Љетопис попа Дукљанина, 1988, стр. 138, 141). Међутим, сам манастир је од оснивања био византијски, а тек касније, при опадању византијске државне моћи и распаду цариградске црквене организације, у крајевима Скадар, Диоклија, Антибар бива преузет од стране Рима. Ово се највјероватније догађа крајем XI вијека, током Гвискардових освајања Драча и територија Ипира и Тесалије према централној Грчкој. Наиме, податак који нас може навести на закључак да је на крају обављена регуларна церемонија крунисања јесте слика у Римокатоличкој Цркви светог Михаила у Стону, чији је ктитор највероватније био сам Михаил. На зиду те цркве Михил је приказан са круном какве су имали и западни краљеви (Благојевић, Медаковић,

25 Реченица из папске посланице написане 1078. године гласи: „Дубровник, правни положај да потражује и такође канонско образложење, част своју краљевства нама признату“, лат. "Ragusanum, justitia posit inquiri ac canonice definiri, tuique regni honor a nobis cognosci“ (Farlato, Coleto, 1817, стр. 22).

${ }^{26}$ „[F]ilii nostri Bodini, regis Sclavorum gloriosissimi...“ (Историја Црне Горе, 1967, стр. 397). 
2000, стр. 71; Историја Црне Горе, 1967, стр. 394). Међутим, ако узмемо у обзир да је храм осликан руком живописца латина - као и већина харамова у приморју, разумљив је претходни чин.

\section{3. Интереси српских владара у Диоклији током XI вијека}

Потреба српских владара је првенствено била заштита самосталности као једног од најважнијих државних интереса. Михаилова и Бодинова држава није била војно конкурентна у односу на своје непосредне сусједе. Стога су они, зависно од снаге противника, врло често мијењали савезнике. Примјера ради, Михаилов други брак је био са Византинком, царевом рођаком (Љетопис попа Дукљанина, 1988, стр. 138), што указује на одређени савез са Византијом, док се његов син Бодин пред Гвискардову офанзиву оженио Јаквинтом (Љетопис попа Дукљанина, 1988, стр. 140), припадницом радикалне норманске струје, из јужне Италије. Такође, били су отворени за сваку сарадњу са новим савезницима, што потврђује и уздизање византијске барске епископије у ранг тада већ римске архиепископије, као и за преписку са Римом. Међутим, због њиховог става, расположење према Михаилу и Бодин у престоници Византије није било сјајно. Ана Комнина и њен муж кесар Вријеније Млађи, свједоци тога доба, описујући догађаје у својим дјелима, двојицу владара и егзархе Далматинаца помињу као непоуздане савезнике (Migne, 1864в, стр. 174-176, $365,405)$ и оне који лоше управљају Илириком (Migne, 1864ס, стр. 144-145).

Претходно мишљење поткрепљују догађаји описани у средњовјековним списима, а поготово „Алексији“, која описује учешће Бодина и његове војске у бици код Драча. Егзарси Далмације су тражили најбоље рјешење у том тренутку, које је гарантовало њихову будућност. Стога за неке нелогични савез са најмоћнијим човјеком Драча, Мономахатом, за поменуте је и имао смисла.

Сукоб двије моћне државе тога добе, Византије и Нормандије, на границама Михаилове и Бодинове државе није потврдио савез поменутих држава са српским владарима. Наиме, и император и Гвискард су очекивали потврду савеза од стране Михаила, као и Бодина, непосредно пред сукоб, међутим, она је изостала. „Егзарси Далматинаца“ се одлучују на сасвим треће рјешење, за Мономахата. Он је, у том тренутку, у подручју Драча имао највеће војне могућности. Мономахатос је, према Анином свједочењу, савезништво са Михаилом и Бодином придобио лукавством. Док су Византија и Гвискард очекивали позитивни одговор њих двојице, Мономахатос је договор купио: „Бодина и Михаила ексархе Далмације начинио је пријатељима преко својих писама и даровима је утицао на њихово мишљење... ${ }^{{ }^{27}}$. Савез са Мономахатом је био краткорочан. У из-

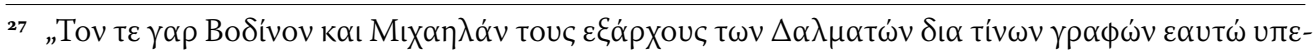

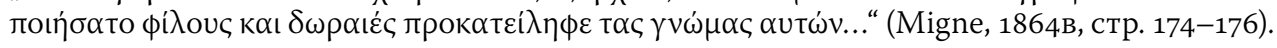


ворима не наилазимо на позив Бодину пред битку код Драча упућен од стране византијског цара, али се он током битке појављује међу угледним војсковођама. Приједлог Бодина, као и осталих старијих бораца „са искуством“, цару јесте да се не упуштају у директну битку, него да размјењују хице и да стрпљиво чекају, и да тако Гвискарда у тактици поремете. Бодин и остали су увјеравали цара да ће на тај начин брзо поразити Гвискарда ${ }^{28}$. Међутим, стратегија одабрана по наговору млађих војсковођа није уродила плодом. Византија је 1081. године поражена код Драча. Осјетно је велико разочарање византијске стране по питању учешћа Бодина у бици. Писац велики дио одговорности за пораз пребацује управо на Турке и Бодина, који се повлаче са бојнога поља: „Пошто је видио Турке како одлазе, и овога Бодина ठез ратовања да се повлачи..." ${ }^{29}$. Међутим, пратећи сам ток ठитке, долазимо до закључка да се пораз Византије и савезника десио знатно раније, када је Гвискард разбио цареве формације, што је резултирало смрћу великог броја војника, али и припадника Палате, међу којима је био и Константин, син Константина Дуке, рођен у Порфири (Migne, 1864в, стр. 360-361). Поразом византијске војске код Драча 1081. године, за једно кратко време, Гвискард постаје одлучујући војни фактор на јадранским обалама. Сам је држао један велики дио приморја у јужној Италији и дио обале поред Драча са полуострвом Глосом и острвом Крфом. То су били главни поморски путеви које је Гвискард надгледао својом флотом (Migne, 1864в, стр. 405). Бодин, након пада Драча, са својим одредима учествује у походима на византијске територије у Ипиру и Македонији, које је предводио нормански војсковођа Петар Алифа. Из извора сазнајемо да је Бодин (Migne, 1864в, стр. 405) 1082. године освојио византијски град Моглен ${ }^{30}$.

Једанаести вијек је на простору Михаилове и Бодинове државе Михаила и Бодина окарактерисан као доба ратова, дипломатских савезништава и преговора. Успони и падови Византије и Нормана смијењивали су се и доносили различите утицаје на Илирик. Први пут након 732. године званични Рим преговара о повратку својих надлежности у источни Илирик, на целокупну територију гдје живе Срби. Међутим, стварност XI вијека је сасвим другачија. У простом народу велики успон доживљава култ Светог Јована Владимира, са центром изнад града (Анти)бара, преко

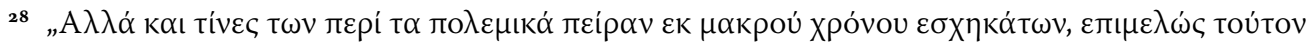

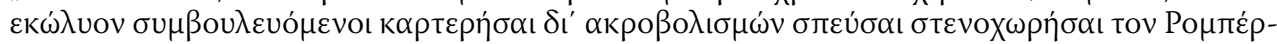

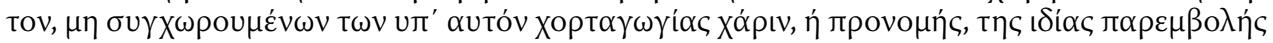

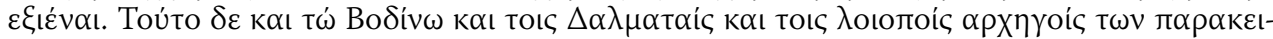

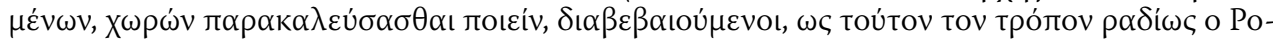

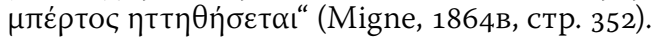

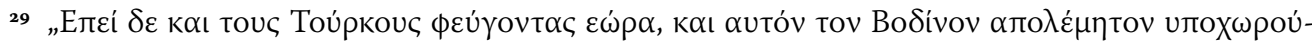
vта..." (Migne, 1864B, стр. 365).

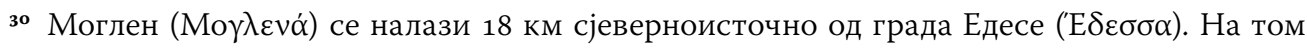
мјесту је данас разрушени дворац. 
планине Румије у манастиру Пречиста Крајинска. Манастирски комплекс је дозићиван управо у овом раздобљу. Хришћанство код Срба ХІ вијека је већ дубоко утемељено, поготово због пројављивања светитеља из сопственог народа, из краљевске лозе. Источни обичаји су били неодвојиви дио хришћанства код Срба.

\section{Литература:}

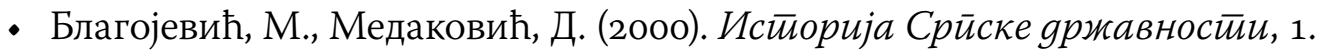
Нови Сад.

- Darrouzes, J. (1981). Notitiae Episcopatuum Ecclesiae Constantinopolitanae. Paris: Institut Francais D'Etudes Byzantines.

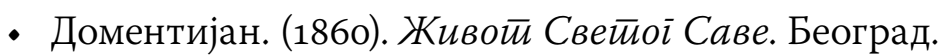

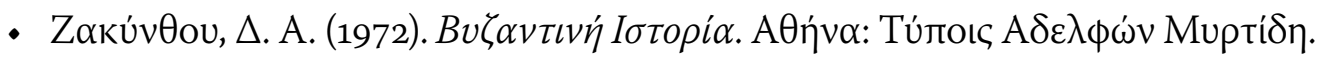

- Исйорија Црне Горе. (1967). Титоград: Редакција за историју Црне Горе.

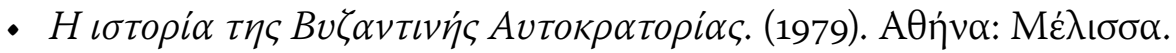

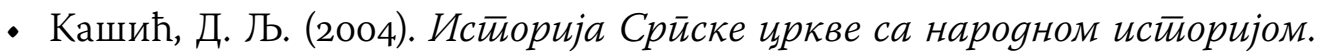
Београд: Свети Архијерејски Синод СПЦ.

- Comnenae, A. (2001). Aleksias. Corpus Fontium Historiae Byzantinae Series Berolinensis.

- Линч, Џ. (1999). Ист̄орија среgњовјековне Цркве. Београд: Clio.

- Љейойис ӣoйа Дукљанина. (1988). Београд: Просвета.

- Migne, J. P. (1864a). Patrologiae Cursus completus Series Graeca, 120. Paris.

- Migne, J. P. (1864ס). Patrologiae Cursus completus Series Graeca, 127. Paris.

- Migne, J. P. (1864B). Patrologiae Cursus completus Series Graeca, 131. Paris.

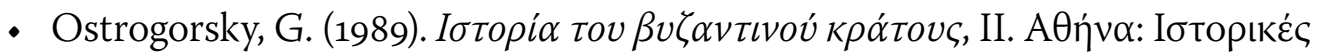

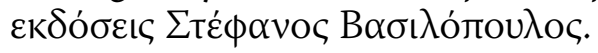

- Острогорски, Г. (1996). Истиорија Визанӣије. Београд: Просвета.

- Стефан Првовенчани, (1988). Живой свейоїа Симеона. Београд: Стара српска књижевност.

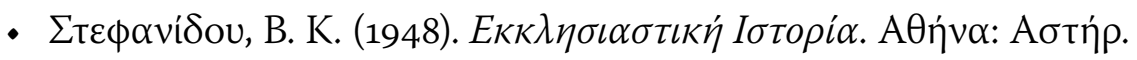

- Farlato, D., Coleto, J. (1817). Illyrici Sacri, 7. Apud Sebastianum Coleti.

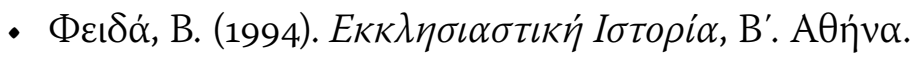

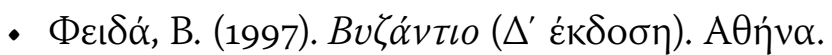


Radovan Radić

Christian Cultural Centre, Belgrade

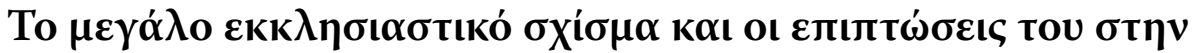

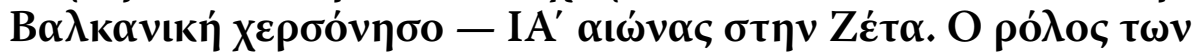

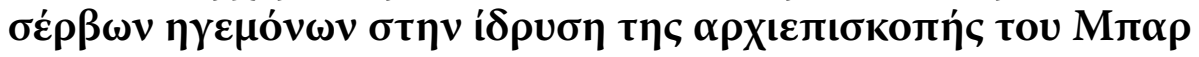

$\mathrm{H}^{\mathrm{e}}$

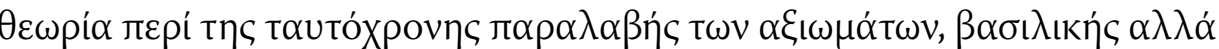

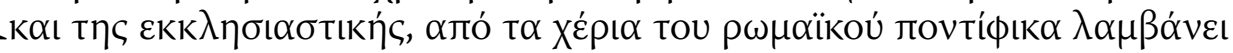

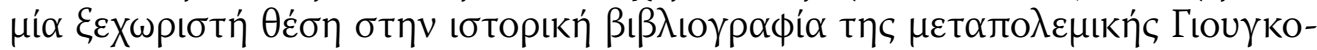

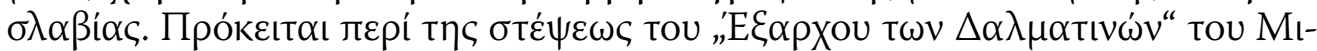

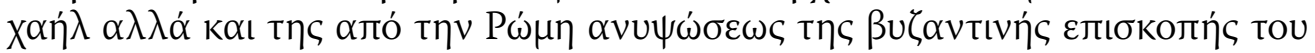

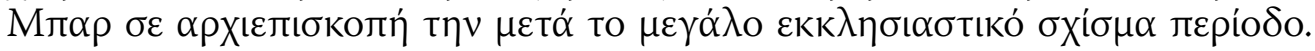

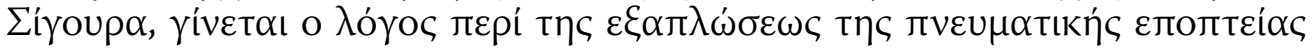

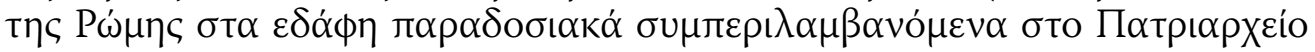

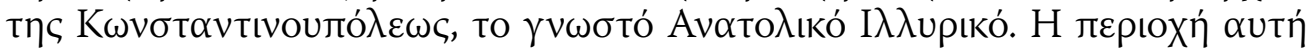

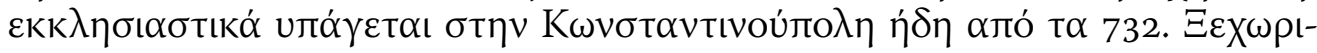

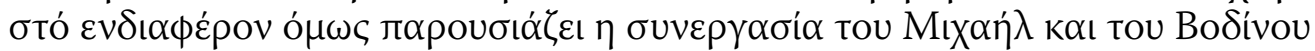

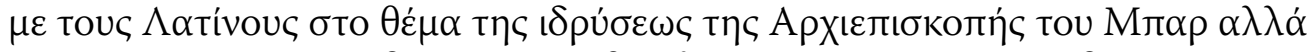

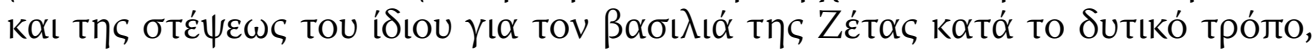

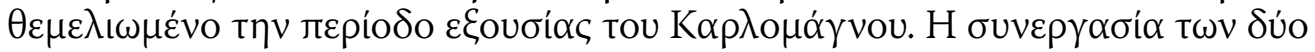

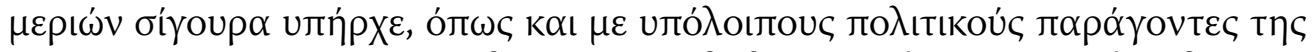

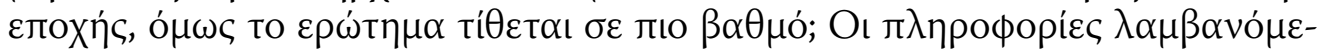

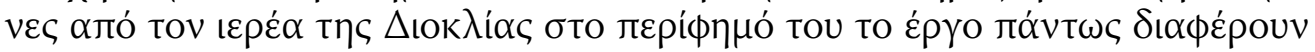

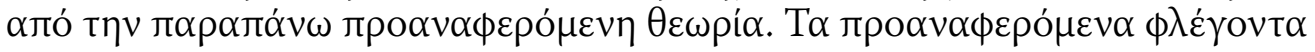

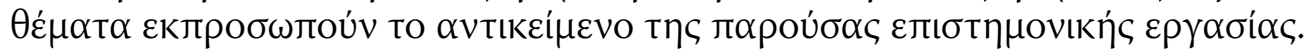

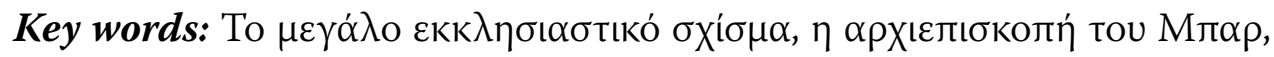

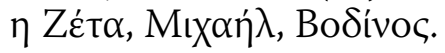

Датум пријема чланка: 27. 6. 2013.

Датум прихватања чланка за објављивање: 5. 12. 2013. 